DOI: 10.34015/2523-4552.2020.1.10

удк 343.2

Новікова К. А.,

кандидат юридичних наук, старший науковий співробітник Науково-

дослідного інституту вивчення проблем злочинності імені академіка

В. В. Сташиса Національної академії

правових наук України

ORCID: 0000-0001-8646-3441

\title{
КРИТЕРІЇ ОБМЕЖЕННЯ ПРАВА НА ОСОБИСТУ СВОБОДУ ЛЮДИНИ В ЗАХОДАХ КРИМІНАЛЬНО-ПРАВОВОГО ХАРАКТЕРУ
}

Стаття присвячена визначенню меж державного впливу на особисту свободу людини. Розвивається вироблений практикою Європейського суду 3 прав людини «трискладовий тест»: у рамках трьох елементів пропонується виділити критерії меж впливу на особисту свободу людини, а саме: в межах законності пропонується розглядати строковість, в межах обгрунтованості крайність, в межах необхідності обмеження прав і свобод людини - пропорційність (співрозмірність) таких обмежень.

Ключові слова: особиста свобода; покарання; заходи кримінальноправового характеру.

Статья посвящена определению границ государственного влияния на личную свободу человека. Развивается предложенный практикой Европейского суда по правам человека «трехсоставляющий тест»: в рамках трех элементов предлагается выделить критерии границ влияния на личную свободу человека, а именно: в рамках законности предлагается рассматривать срочность, в пределах обоснованности - крайность, в пределах необходимости ограничения прав и свобод человека - пропорциональность (соразмерность) таких ограничений.

Ключевые слова: личная свобода; наказание; меры уголовно-правового характера.

Постановка проблеми. Кримінальне право - галузь права, яка намагається врегулювати конфлікт між людиною і державою. 3 одного боку, держава зобов'язана піклуватися про суспільство, якому часто вигідно, щоб правопорушник був ізольований від суспільства. 3 іншого боку, держава не тільки обмежує, а й захищає права цього самого правопорушника.
Стаття 1 Загальної декларації прав людини проголошує, що усі народжуються вільними та рівними у своїх правах. Держава обмежує свободу заради досягнення високої цілі - суспільно корисного результату.

По-перше, такі обмеження можуть бути не лише в сфері кримінального права, а і в інших галузях права, наприклад, адміністративного 
права. У цій статті досліджуються тільки обмеження права на особисту свободу у сфері кримінального права. По-друге, ці обмеження не мають бути довільними.

Постановка завдання. Визначити межі державного впливу на особисту свободу людини і визначити групи критеріїв обмеження права на особисту свободу людини.

Аналіз останніх досліджень і публікацій. Питання обмеження окремих прав людини $\epsilon$ предметом уваги конституціоналістів та теоретиків права: П. М. Рабіновича, В. В. Речицького, Ю. М. Тодики та інших відомих вчених. Що ж стосується кримінального права, то проблема обмеження права особистої свободи людини досліджувалася лише в межах аналізу окремих заходів, таких як обмеження волі, арешт, позбавлення волі, довічне позбавлення волі, примусові заходи медичного характеру, обмежувальні заходи тощо, i не була предметом окремого дослідження.

Виклад основного матеріалу. Для того, щоб визначитися з межами допустимого впливу на особисту свободу людини у кримінальному праві, слід хоча б побіжно звернутися до самого поняття «особистої свободи» і до тих теоретичних моделей обмежень, які пропонують вчені науки теорії та конституційного права.

Особиста свобода становить собою мінімальний обсяг незалежності, яку індивіди зберігають за собою, погоджуючись підкорятися закону $[1$, c. 44]. Єдиним виправданим втручанням у свободу будь-якої людини $\epsilon$ попередження шкоди, яка може бути заподіяна іншим. Свободу можна обмежувати, але ці обмеження мають відповідати певним критеріям [2, c. 286]. Проблемою $є$ не можливість обмеження прав як така, а межі пропонованих обмежень, які призвані захистити права від їх повного вихолощення. Свобода індивіда розуміється не тільки як свобода від впливу на його діяння, свобода може потребувати також вчинення позитивних діянь з боку держави [3, с. 46].

Як вже зазначалося, держава обмежує свободу заради суспільно корисного результату. Але громадянин може поставити під сумнів спрямованість закону на досягнення суспільного блага [4, с. 83]. Для того, щоб дотримувався принцип врахування суспільної думки, законодавець має використовувати соціально-економічні підстави криміналізації або інших елементів кримінально-правової політики [див. 5, с. 76].

Обмеження відіграють величезну роль у здобутті особистістю справжньої свободи. Обмежуючи певною мірою свободу кожного індивіда, закон забезпечує йому безперешкодне використання своїх прав, тобто гарантує йому свободу всередині цих меж. Свобода кожної людини поширюється лише до тієї межі, від якої починається свобода інших людей. Прагнучи встановити ці межі, закон сприяє тому, щоб у спільному житті людей запанував порядок, оснований на свободі [6, с. 359].

Особиста свобода у кримінальному праві обмежується цілою низкою заходів кримінально-правового характеру. Це і покарання, й інші заходи кримінально-правового характеру (наприклад, примусові заходи медичного характеру, примусові заходи виховного характеру, обмежувальні заходи тощо). Зрозуміло, що ступінь обмеження особистої свободи в кожному конкретному випадку 
різний і залежить ще від загальних правил не тільки призначення покарання, а й в широкому сенсі правил застосування заходів кримінальноправового характеру. Так де ж знаходиться межа допустимих обмежень прав та свобод людини? Очевидно, на межі критеріїв обмеження права на особисту свободу людини.

Слід зазначити, що Європейський суд $з$ прав людини, його «трискладовий тест» визначив три елементи обмеження прав людини: легальність (законність), обгрунтованість та необхідність обмеження прав i свобод людини в демократичному суспільстві (пропорційність). Попри те, що Європейський суд 3 прав людини говорив про загальні обмеження прав людини, їх можна застосувати і щодо обмеження права на особисту свободу людини. Розвиваючи позиції Європейського суду з прав людини, слід зазначати що врахування його практики і взагалі міжнародно-правових актів $\epsilon$ важливою складовою діяльності правозастосовчих органів. Самі по собі міжнародно-правові акти встановлюють певні рамки на обмеження прав особистої свободи людини.

Так, в Мінімальні стандартні правила поводження 3 в'язнями (п. 27) дозволяються застосовувати тільки ті обмеження, які потрібні для забезпечення надійного нагляду i дотримання належних правил спільного життя в установі. В'язням (п. 37) дозволяється спілкуватися через регулярні проміжки часу і під належним наглядом з їхніми сім'ями або друзями, що мають бездоганну репутацію, як шляхом листування, так і безпосередньо, в ході відвідин. Прогалиною $\epsilon$ те, що такі правила визначаються на міжнародному рівні для осіб, які обмежуються особистої свободи в вузькому сенсі (різні види ув'язнення). А як же бути з тими обмеженнями особистої свободи, які застосовуються під час виконання інших видів покарань або інших заходів кримінально-правового характеру? Очевидно, що це питання потребує свого правового врегулювання.

Стаття 10 Міжнародного пакту про громадянські та політичні права закріплює, що всі особи, позбавлені волі, мають право на гуманне поводження і поважання гідності, властивої людській особі. Незважаючи на захищені в Україні дисертації [див. 7; 8], науці кримінального права не вдалося визначити чітке поняття що таке «гуманність». I гуманізм і досі залишається абстрактним поняттям, потребуючим визначення чіткості меж.

Європейські пенітенціарні правила (п. 3) закріплюють положення про те, що обмеження, накладені на осіб, позбавлених волі, повинні бути мінімально необхідними та відповідати тій обгрунтованій меті, з якої вони накладалися. Цікавим $€$ той факт, що навіть при позбавленні особистої свободи засоби обмеження свободи руху ніколи не повинні застосовуватися для покарання (п. 60.1.6). Тоді, якщо детально розглядати примусові заходи медичного характеру - госпіталізація до закладу 3 надання психіатричної допомоги (ч. 1 ст. 94 КК України), то там такий захід застосовується дуже часто.

Європейський суд з прав людини теж вносить свій внесок в інтерпретацію стандартів обмеження особистої свободи, шляхом розширення його - тлумаченням права на гуманне ставлення. Навіть в умовах обме- 
ження права на особисту свободу залишаються мінімальні гарантії цього гуманізму і таке інше. Часто зміст принципу гуманізму зводиться до заборони нелюдського поводження, заборони катувань тощо (наприклад, справа Сааді проти Італії від 28.02.2008), але він значно ширший. Кожне звернення до ЄСПЛ може кардинально змінити підхід до інтерпретації того чи іншого права чи свободи для всього світу та України зокрема [7, с. 163-164]. Таким чином, обмеження особистої свободи людини мають встановлюватися 3 дотриманням міжнародних стандартів.

Уточнюючи «трискладовий тест» Європейського суду з прав людини, який визначив три елементи обмеження прав людини: легальність (законність), обгрунтованість та необхідність обмеження прав $\mathrm{i}$ свобод людини в демократичному суспільстві (пропорційність), слід виокремити ті критерії, які мають суттєве значення для заходів кримінально-правового характеру.

Так у рамках першого елементу слід підкреслити важливе значення не тільки встановлення законом цих заходів, а потрібно, щоб було визначено вид та строк заходів, які обмежують особисту свободу. Обмеження особистої свободи людини має строковий характер. Так, у Загальній частині КК України визначаються максимальний строк, на який призначається арешт (до 6 місяців), обмеження волі (до 5 років), тримання в дисциплінарному батальйоні військовослужбовців (до 2 років) та позбавлення волі на певний строк (до 15 років), у випадку призначення покарання за сукупністю вироків до 25 років. Навіть довічне позбавлення волі, хоч і визнається безстро- ковим видом покарання, має умовно строковий характер у зв'язку із можливістю бути помилуваним - п. 4 Положення про порядок здійснення помилування (так зване «право на надію»). Мінімальна свобода $\epsilon$, навіть, при максимальних обмеженнях - наприклад, особи, які відбувають довічне позбавлення волі, мають права на щоденні прогулянки, на користування книжками тощо.

Аналізуючи інші заходи кримінального правового характеру, можна помітити теж строковий характер. Так, примусові заходи медичного характеру переглядаються не рідше ніж раз на 6 місяців (ст. 95 КК України). Тривалість примусових заходів виховного характеру встановлюється судом (ст. 105 КК України), хоча у порядку de lege ferenda можна замислитися про необхідність законодавчого встановлення таких строків. Обмежувальні заходи можуть застосовуватися на строк від одного до трьох місяців і за потреби можуть бути продовжені на визначений судом строк, але не більше як на 12 місяців (ст. 91ํКК України).

Строковість можна поділити на встановлену у законі та гіпотетично можливу строковість. Мною помічено, що в жодній Конвенції, в жодній Конституції світу не закріплені ці рамки, межі обмеження особистої свободи людини. Але дослідження більшості країн показало, що кримінальним законодавством встановлюються строки обмеження особистої свободи, при цьому строки найрізноманітніші. Довічне ж позбавлення волі у світі зустрічаються відносно рідко.

У рамках обгрунтованості слід вирізнити такий критерій як крайність. Окрім цього, обов'язково по- 
винні бути диференційовані заходи кримінально-правового характеру, які мають встановлювати різноманітні рамки обмеження прав і свобод людини. Примусові ж заходи медичного характеру визнаються найсуворішими серед них, оскільки правообмежувальними заходами серед них $\epsilon$ навіть обмеження фізичної свободи людини.

Заходи пов'язані з обмеженням особистої свободи, мають бути крайніми, тобто застосовуватися тоді, коли по-іншому не можна. Свобода - це найцінніше людське благо. Європейський суд 3 прав людини однозначно став на позицію людиноцентристського підходу, захищаючи невід'ємне право у тому числі на свободу.

Свобода - може розглядатися як комплекс прав, врегульованих законом, а саме право - в об'єктивному значенні як закон, що регулює свободу [9, с. 51]. Саме тому свобода людини не безмежна, а визначена певними рамками [10, с. 19]. Відомо, що заходи кримінального права застосовуються за принципом ultima racio, так от заходи, пов'язані із обмеженням особистої свободи, повинні застосовуватися тоді, коли всі засоби кримінально-правового реагування вже вичерпані і правозастосовувачу тільки й залишається, що обмежити особисту свободу людини. Це означає, що доти, доки правозастосувач потенційно не використає увесь арсенал заходів, не пов'язаних з обмеженням особистої свободи, переходити до обмеження особистої свободи не можна.

Нарешті, обмеження особистої свободи людини має бути співрозмі- рним тому діянню, яке вчинене (принцип пропорційності). Співрозмірність (пропорційність) у праві являє собою загальний, універсальний принцип права, який вимагає співрозмірного обмеження прав i свобод людини для досягнення публічних цілей $[11$, с. 42$]$. Принцип пропорційності (балансування) часто використовується як спосіб визначення того, чи були основні права обмежені правомірним шляхом чи порушені в результаті неправомірного впливу [3, с. 46]. Правопорушення (злочини) поділяються на категорії (ст. 12 КК України) і кожне 3 цих правопорушень умовно встановлює визначені рамки для застосування потенційних меж заходів кримінально-правового характеру. Це означає, що оцінюється потенційна істотна шкода, заподіяна діянням, і потенційний захід, який можна застосовувати за діяння, яке заподіяло таку шкоду.

Висновки. Вирішуючи питання співрозмірності й граничної допустимості можливості обмеження прав і свобод людини, слід відзначити, що таке обмеження має відповідати певним критеріям. Розвиваючи усталену практику Європейського суду 3 прав людини, в рамках «трискладового тесту» можна виокремити такі критерії як строковість обмеження особистої свободи, крайність та пропорційність. При цьому я не претендую на вичерпність цього переліку і вважаю, що його покращення $\epsilon$ перспективним для подальшої науки кримінального права. 


\section{Список використаних джерел}

1. Таманага Б. Верховенство права. Історія. Політика. Теорія. Переклад з англійської А. Іщенка. Київ : Видавничий дім «Києво-Могилянська академія». 2007. 208 с.

2. Ролз Д. Теорія справедливості. Пер. з англ. О. Мокровольський. Київ : Вид-во Соломії Павличко «Основи». 2001. 822 с.

3. Троицкая А. Пределы прав и абсолютные права: за рамками принципа пропорциональности? Теоретические вопросы и практика Конституционного Суда РФ. Сравнительное конституционное обозрение. Москва : Институт права и публичной политики. 2015. № 2 (105). С. 45-69.

4. Аллан Т. Р. С. Конституційна справедливість. Ліберальна теорія верховенства права. Пер. $з$ англ. Р. Семківа. Київ : Вид. дім «Києво-Могилянська академія». 2008. $385 \mathrm{c}$.

5. Коробеев А. И. Советская уголовно-правовая политика. Проблемы криминализации и пенализации. Владивосток : Изд-во Дальневосточного университета. 1987. 268 c.

6. Фігель Ю. О. Теоретичні аспекти обмеження прав людини. Вісник Національного університету «Львівська політехніка». Юридичні науки. 2016. № 837. С. 357-361.

7. Тімофєєва Л. Ю. Гуманістична парадигма кримінального права України: дис. ... канд. юрид. наук: 12.00.08. Одеса, 2018. 277 с.

8. Резнік Ю. С. Принцип гуманізму та його реалізація в кримінальному праві України: автореф. дис. ... канд. юрид. наук : 12.00.08 / НАН України, Ін-т держави і права ім. В. М. Корецького. Київ, 2017. 20 с.

9. Возгрін С. Ю. Межі свободи та заборона обмеження прав і свобод людини: національно-правовий та міжнародні аспекти. Науковий вісник Міжнародного гуманітарного університету. Сер.: Юриспруденція. 2013. № 6-3. Том 1. С. 51-54.

10. Новікова К. А. Обмеження особистої свободи як вид покарання: монографія / наук. ред. Ю. А. Пономаренко. Харків : Право, 2019. 288 с.

11. Майданик Р. А. Пропорційність (співрозмірність) і право власності: доктрина і судова практика. Право України. 2016. № 1. С. 41-54.

\section{References}

Tamanaha, B. (2007). Verkhovenstvo prava. Istoriia. Polityka. Teoriia. Pereklad z anhliiskoi A. Ishchenka. Kyiv: Vydavnychyi dom «Kyievo-Mohylianska akademiia» [in Ukrainian].

Rolz, D. (2001) Teoriia spravedlyvosti. Per. z anhl. O. Mokrovolskyi. Kyiv: Vyd-vo Solomii Pavlychko «Osnovy» [in Ukrainian].

Troickaja, A. (2015). Predely prav i absoljutnye prava: za ramkami principa proporcional'nosti? Teoreticheskie voprosy i praktika Konstitucionnogo Suda RF. Sravnitel'noe konstitucionnoe obozrenie, 2 (105), 45-69 [in Russian].

Allan, T. R. S. (2008). Konstytutsiina spravedlyvist. Liberalna teoriia verkhovenstva prava. Per. z anhl. R. Semkiva. Kyiv: Vyd. dim «Kyievo-Mohylianska akademiia» [in Ukrainian].

Korobeev, A. I. (1987). Sovetskaja ugolovno-pravovaja politika. Problemy kriminalizacii i penalizacii. Vladivostok: Izd-vo Dal'nevostochnogo universiteta [in Russian].

Fihel, Yu. O. (2017). Teoretychni aspekty obmezhennia prav liudyny. Visnyk Natsionalnoho universytetu «Lvivska politekhnika». Yurydychni nauky, 837, 357-361 [in Ukrainian].

Timofieieva, L. Yu. (2018). Humanistychna paradyhma kryminalnoho prava Ukrainy (Dys. ... kand. yuryd. Nauk). Odesa [in Ukrainian]. 
Reznik, Yu. S. (2017). Pryntsyp humanizmu ta yoho realizatsiia $v$ kryminalnomu pravi Ukrainy (Avtoref. dys. ... kand. yuryd. Nauk). NAN Ukrainy, In-t derzhavy i prava im. V. M. Koretskoho. Kyiv [in Ukrainian].

Vozghrin, S. Yu (2013). Mezhi svobody ta zaborona obmezhennia prav i svobod liudyny: natsionalno-pravovyi ta mizhnarodni aspekty. Naukovyi visnyk Mizhnarodnoho humanitarnoho universytetu. Ser.: Yurysprudentsiia, 6-3, 1, 51-54 [in Ukrainian].

Novikova, K. A. (2019). Obmezhennia osobystoi svobody yak vyd pokarannia. Kharkiv: Pravo [in Ukrainian].

Maidanyk, R. A. (2016). Proportsiinist (spivrozmirnist) i pravo vlasnosti: doktryna i sudova praktyka. Pravo Ukrainy, 1, 41-54 [in Ukrainian].

K. Novikova, PhD, Senior Researcher of Academician Stashis Scientific Research Institute for the Study of Crime Problems of the National Ukrainian Academy of Law Sciences

ORCID: 0000-0001-8646-3441

\section{Criteria for limiting the right to personal freedom in the measures of criminal legal nature}

The article is devoted to defining the limits of state influence on personal freedom. Personal freedom and theoretical models of restrictions on the right to personal freedom of man are analyzed. Measures restricting the rights to personal freedom of person are distinguished. It is determined that coercive measures of a medical nature are the most stringent among the measures restricting personal freedom, since they also allow the actual physical restriction of the right to personal freedom.

The importance of the case-law of the European Court of Human Rights is emphasized and it is stated that international legal acts establish a certain framework for restricting the rights to individual human freedom. The three-part test developed by the European Court of Human Rights is being developed, which has identified three elements of human rights restriction: legality (legality), validity and necessity of restriction of human rights and freedoms in a democratic society (proportionality). Within these elements it is proposed to distinguish the criteria of the limits of influence on personal freedom of man, namely: within the limits of legality it is proposed to consider the urgency, within the justification - the extreme, in the framework of the need to restrict human rights and freedoms - the proportionality (proportionality) of such restrictions. Therefore, these three criteria must be met by the restriction of the right to personal freedom of person when deciding on the issue of proportionality and maximum admissibility.

Keywords: personal freedom; punishment; measures of criminal legal nature. 